\title{
Nonsense on Stilts
}

\author{
Julian Petley
}

Policies formulated in response to ill-informed and raucously populist press campaigns are likely to be as vacuous as the newspaper columns which inspired them. And so it is with David Cameron's incoherent and juridically illiterate plan to scrap the Human Rights Act (HRA) and replace it with a 'British Bill of Rights and Responsibilities'.

As I explained in 'Anyone for freedom of expression?' (Index 32: 4), press hostility to the HRA dates back to its birth, which the press feared (wrongly) would bring about a privacy law. But it also had deeper roots in conservative opinion's hostility to anything smacking of 'European' ideas, human rights amongst them. And it is this strain of thinking that has come right to the fore in the renewed assault on the HRA in Britain's illiberal press.

The immediate cause of the latest, and loudest, outbreak of press hostility to the HRA was the most recent episode of the saga of the nine Afghans who hijacked an internal flight from Kabul in February 2000 and forced it to land at Stansted airport.

Shortly after the hijack, the then Home Secretary Jack Straw stated that the men would be deported 'as soon as is reasonably practicable'. However, in July 2004 an immigration adjudication panel ruled that they could not be returned to Afghanistan as this would be in contravention of Article 3 of the ECHR - which concerns the right not to be subjected to inhuman or degrading treatment. They were then left in limbo by the Government failing formally to permit them to enter the country. In July 2005, a new Home Secretary, Charles Clarke, introduced asylum policy measures giving him new discretion to refuse entry to applicants who fell within certain 'exclusion criteria'. In November he declared that the nine did so, and that, consequently, it would be inappropriate to grant them discretionary leave to remain. The men challenged this, and, in May 2006, won the right to stay until it was safe to return home.

Delivering his verdict, Mr Justice Sullivan was exceptionally critical of the treatment of the hijackers, accusing the Home Office of 'a transparent attempt to find a form of words that would enable the defendant [the Home Secretary] to defy the adjudicators' decision without having to acknowledge that he was doing so', adding that he 'deliberately delayed giving effect to the adjudicators' decision in order to give himself time to devise a revised policy which would 
purportedly justify not implementing the adjudicators' decision'. The judge referred to Clarke's July 2005 measures as 'a paradigm of a minister being given unfettered administrative discretion to depart from a published policy whenever he thinks it appropriate to do so' and concluded that: 'it is difficult to conceive of a clearer case of "conspicuous unfairness amounting to an abuse of power"'. And in order to indicate 'the strongest mark of the court's disapproval' and to register his 'disquiet and concern', he ordered the Home Office to pay legal costs on an indemnity basis - the highest level possible - estimated at $£ 200,000$.

This was certainly a stinging rebuke, and unsurprisingly Tony Blair immediately complained that: 'we can't have a situation in which people who hijack a plane we are not able to deport back to their own country. It is not an abuse of justice for us to order their deportation. It is an abuse of common sense'. But what line did the majority of the press take? Denounce a flagrant abuse of government power, as the so-called Fourth Estate might be expected to do? Or side with the government, denounce the judge and excoriate the HRA? Most papers unhesitatingly chose the latter course.

Thus the Sun, 11 May, in a leader headed 'A stupid law' called the HRA 'ludicrous' and stated that: 'last year, Tony Blair vowed to scrap the human rights laws if they undermined the war on terror. Holding a country to ransom at gunpoint apparently doesn't qualify'. The following day, in a further leader, entitled 'Time to stop this madness', the Sun launched what it called 'a proud campaign to put an end to the human rights madness that is horrifying this country', adding that: 'we applaud David Cameron for pledging that the Tories would tear up crazy human rights laws, and we urge Tony Blair to get on and do this while he remains in power', something which, it claims, 'all Britain is crying for'. According to the Sun: 'the whole concept of "human rights" in Britain has become a travesty under which the interests of killers, rapists and paedophiles are placed above those of their victims. Law abiding citizens must walk in fear while "human rights" give their assailants the freedom of the streets'. Thus, it promised, 'the Sun will continue to expose human rights madness wherever we see it'.

Meanwhile, in the Mail, 12 May, under the headline 'Yes, but what about OUR human rights?', Max Hastings lambasted 'the exploitation of liberal legislation to serve the undeserving and make a mockery of the generosity of the British people'. According to Hastings: 'what has gone wrong, shockingly and disgracefully wrong, is that the world has changed out of recognition over the past half-century, while the provisions of the Universal Declaration have never been revised. The liberal democracies of Europe have allowed themselves to become prisoners of a fine-sounding fragment 
of postwar rhetoric, in utterly changed circumstances'. And the main change, according to Hastings, is 'large-scale migration', which means that 'if an Afghan, Nigerian or Chinese can contrive by any means, legal or illegal, to place themselves within our jurisdiction, they enjoy the full protection of this hopelessly outdated document'. The Convention should thus be re-drafted to meet the requirements of the modern world. Until this happens, he argues, 'every kind of lawbreaker and freeloader will continue to come here and make fools of our society ... Thousands of decisions are being made daily in the name of human rights which we never hear about, but which cost us money and grant privileges to foreigners in this country to which they have no conceivable moral claim ... It is crazy, yet such craziness will repeated again and again until we change this rotten law'. In similar vein, a leader in that day's paper argued that the principle of human rights 'has been twisted into a charter for terrorists and criminals'.

In the Sunday Times, 14 May, Simon Jenkins' article 'Basic freedoms are being lost in the human rights circus' approvingly quoted Bentham to the effect that the concept of human rights is 'nonsense on stilts' and argued that 'there are no fundamental human rights'. This at least had the merit of being based on a coherent philosophical position, and actually made the perfectly sensible point that 'human rights tend to be mere platitudes unless expressed as concrete liberties, preferably in a written constitution'. Sense, however, is almost completely absent from what can only be described as a rant by Carole Malone in the same day's Sunday Mirror. Under the headline 'They hijacked all our rights', the Act is dismissed as a 'farce' and the product of 'loony liberalism', and Malone shrieks that: 'we're sick of it. We're sick of OUR human rights coming second to those of terrorists, hijackers and health tourists ... in fact anyone who fancies a free house, car and health care. We're sick of the fact that every time we object to these people being given precedence over those who were born in this country and who contribute towards its upkeep, we're denounced as racists. We're sick of being told that everyone who arrives in this country, legally or otherwise, has "rights" Well they don't actually. Freeloaders, criminals and people who lie to get here shouldn't have the same rights as the rest of us'.

On Monday 15 May it was, inevitably, the turn of Melanie Phillips in the Mail, who, under the give-away headline 'If we really want to escape the grip of human rights law we must quit the EU', stated that the HRA 'has quite simply altered the entire legal and moral culture of this country, and taken an axe to common sense'. Denouncing the Act for creating 'a culture of legalised lunacy' she argued that: 'ruling after human rights ruling has turned right and wrong on their heads and radically undermined the covenant of responsibility between the individual and the state'. In her usual wearyingly apocalyptic tone, she continued: 'human rights law has driven justice, morality 
and social order off the rails altogether. It has acted as a grievance charter fuelling the "victim culture" in which all minorities are seen as incapable of being held responsible for their actions. As such, it has become a principal weapon against the culture and identity of the nation - and, by transferring power to the judges, has delivered a powerful blow against our democracy'. And in a ludicrously contorted misreading of Lord Bingham's entirely apposite remark that the HRA exists at least partly to protect vulnerable minorities against majority opinion, she concludes that: 'it would seem to follow that - for the judiciary - Afghan hijackers, murderers and other criminals are "vulnerable minorities", while the majority of their potential victims have no human rights at all'. This is simply perverse nonsense, but her conclusion, if entirely predictable, is at least logical. Thus noting that even if the HRA were abolished, Britain, as an EU member, would still be a signatory to the ECHR, Phillips states that: 'we should leave the EU, in order to restore our powers of selfgovernment and democracy'.

The dominant press attitude was summed up by Charles Moore in the Daily Telegraph 20 May, in which he argued that: 'the Human Rights Act is for Tony Blair's Government what the ERM was for John Major - the humiliating failure of its most sacred doctrine'. According to Moore: 'in popular conversation now, "human rights" in this country is the subject of mockery. It is understood, essentially correctly, to be a system by which judges defend bad people from the consequences of their actions and impose duties upon good people which are unreasonable ... Human rights are also understood, also correctly, to be an arrangement by which British citizens derive no advantage from their citizenship and foreigners can now ride on their backs'. The whole article is, in fact, a clarion call for Britain to repeal the HRA and withdraw from the ECHR (and, by implication, the EU). Such sentiments are now almost a daily occurrence across large swathes of the British press, and look set to grow in number and intensity. What we have here - and by no means simply in the Sun - is a concerted campaign.

A number of highly potent ideological strands are interwoven in this campaign. Firstly, there is, as ably demonstrated by Simon Jenkins via Bentham, hostility to the idea of rights per se, an antipathy also to be found in the works of Burke, Dicey and Blackstone. Whether one regards this as robust, English common sense, or the expression of a narrow, cramped, pettifogging empiricism which has crippled much of British intellectual life is, in the end, a matter of philosophical opinion. In the past such antipathy was frequently grounded in hostility towards the French Revolution and what, during and following the Napoleonic era, came to be seen in England as 'European' thinking. As the former Chairman of the Press Complaints Commission, Lord Wakeham, noted during the newspapers' initial skirmishes with the HRA, when the European Convention on Human Rights 
came into being in 1953, Britain 'was unprepared to import alien legal concepts into its sovereign Parliamentary and judicial system'. And this, clearly, is still the view of Britain's atavistic newspapers, and indeed of David Cameron, who referred to the ECHR as a 'foreign convention of rights'. Thus the second ideological strand woven into this campaign, and ably illustrated by Melanie Phillips, is Europhobia.

Fear and dislike of 'Europe', however, is simply one aspect of the third strand, namely xenophobia. This is at its clearest in the article by Max Hastings, whose ridiculous argument that the ECHR has been superseded by the fact of 'mass migration' is detonated by the fact that Europe was still awash with refugees and stateless persons when the ECHR was being drafted, and was about to experience considerable immigration from its former colonies. However, the article isn't seriously concerned with the facts of migration but is simply an opportunity for Hastings to trumpet his outrage that, under the HRA, foreigners have exactly the same rights as he does.

But this, of course, is the whole point about human rights - they are, by definition, universal. This makes utter nonsense not only of Cameron's idea of a 'British Bill of Rights' but of all the paranoid, self-pitying press rhetoric which endlessly whines that certain people, such as foreigners and criminals, have 'more' rights than others. Of course, when a judge takes into consideration the HRA, they will weigh competing rights against each other - for example, the rights of a convicted criminal against the right of the public to live in safety - but this is quite a different matter. However, the point of most papers' coverage of this issue is not to enlighten their readers about the actual workings of the HRA but to enlist it in their Europhobic arsenal and, equally importantly, to use it as a weapon in their unceasing campaign to demonise and ostracise those whom they deem 'other', thus attempting to set the robust majority at the throats of the vulnerable, the weak and the marginal. Which, as Lord Bingham noted, is a key reason why we need the HRA.

Equally significant as the press campaign against the HRA was government reaction to it. Thus within a day of the Sun launching its campaign, papers were confidently asserting that Blair would reform or even repeal the HRA. But while some of this may have been wishful thinking, the Observer, 14 May, revealed that Blair had written to the new Home Secretary John Reid arguing that, in order to ensure that 'the law-abiding majority can live without fear ... we will need to look again at whether primary legislation is needed to address the issue of court rulings which overrule the government in a way that is inconsistent with other EU countries' interpretation of the European Convention on Human Rights.' A Downing Street source was cited to the effect that one option under consideration was to amend the HRA so as to require a 'balance between the rights of the 
individual and the rights of the community to basic security', something which, in his view, British judges did not always take into consideration. The source also stated that the Act could be further amended if British courts blocked moves to deport terror suspects on the basis of 'memorandums of understanding' that they would not be tortured. A further possibility would be for Britain to consider withdrawing from specific clauses of the ECHR if they led to court rulings which placed 'community safety' at risk.

All governments, but especially this one, are excruciatingly sensitive to the charge that they are 'soft' on immigration, asylum, 'European' and law-and-order issues. Unfortunately all of these can be rolled together by newspapers to create a human rights bogeyman. As Lord Lester QC argued in the Guardian 16 May, a wise reaction to the press campaign would have been a major speech from Tony Blair explaining how the HRA 'protects the civil and political rights of everyone, not only minorities: the right to life, and freedom from torture or other ill-treatment; to liberty without arbitrary arrest or detention; to freedom of speech, assembly and association; to fair trials by independent and impartial courts respecting the presumption of innocence; to personal privacy; to a home and private property; to education; and to equal treatment without unfair discrimination'. He could also, Lord Lester continued, explain how the convention 'enshrines British values and shields the governed against abuses of power by their governors. He could recall how the British drafters of the convention made sure that public safety was at its heart, qualifying individual rights with the needs of national security, the prevention of disorder or crime, and the rights and freedoms of others'.

However, this was never going to happen. It's not simply that Blair runs scared of the illiberal press on these matters, but he clearly agrees with them too. Blair has never been a firm supporter of the HRA, a project inherited from John Smith and carried through by Lord Irvine and Jack Straw with Liberal Democrat support. Thus every time the anti-HRA forces have raised their heads, Blair's first reaction has been to cave in. As Lord Lester concluded: 'Mr Blair persists in undermining public confidence in the rule of law and the protection of human rights by the senior British judiciary. Instead of defending the act and the judiciary, he joins the chorus of critics. Having sown the wind of ignorant opposition, he and his government reap the whirlwind'.

Of course, no-one would seriously claim that bringing the HRA into operation has been without its difficulties. But the main problem has been not with its interpretation by the courts but by certain other institutions, most notably the police and prison authorities, whose depth of ignorance about the HRA's actual requirements and workings seems surpassed only by their bureaucratic zealotry in 
enforcing what they take to be its requirements to the last dot and comma. Such ignorance, however, has hardly been dispelled by a government which would apparently rather disown the Act than explain it fully and publicly, and, in particular, by a press which has taken every opportunity to spread, and indeed manufacture, ludicrous myths about its alleged shortcomings. This is a press which, like numerous politicians, Cameron included, endlessly intones the mantra that rights must be accompanied by responsibilities, blissfully ignorant of the basic fact that responsibilities are the corollary not of rights but of power, something which, thanks to the ease with which politicians let themselves be bullied, newspapers possess in abundance. In the case of the HRA, illiberal newspapers have thoroughly abused their power and completely abandoned any responsibility to inform, preferring instead to mount a sustained campaign of vilification and disinformation which not only seriously threatens the rights of all of us but which seems calculated to foment yet more of the social discord, division and disharmony which are now these papers' stock in trade. 